\title{
Surgical versus non-surgical management of patients soon after acute myocardial infarction
}

\author{
R W BROWER, P FIORETTI, M SIMOONS, M HAALEBOS, E N R RULF, \\ P G HUGENHOLTZ
} From the Thoraxcenter and Interuniversity Cardiology Institute, Erasmus University, Rotterdam, the
Netherlands

SUMMARY Of 510 patients admitted to hospital with acute myocardial infarction, 34 had coronary artery bypass grafting before discharge (6-43 days (median 20 ) after infarction). The patients who were given grafts generally had a smaller infarction with less functional impairment than the 476 patients who were not. The outcome of coronary artery bypass grafting was investigated in a retrospective matched pair study. Patients were matched on the basis of the presence of postinfarction angina, left ventricular ejection fraction, location of the infarction, peak creatine kinase activity, Killip clinical class, and severity of coronary disease with 34 patients who were given medical treatment only. At one year follow up fewer of the operated patients had symptoms than did the matched non-operated patients. Survival at one year in the operated and non-operated groups respectively was $94 \%$ vs $91 \%$; angina within one year occurred in $3 \%$ vs $68 \%$; congestive heart failure in $3 \%$ vs $6 \%$; and $0 \%$ vs $32 \%$ were referred for later bypass grafting or coronary angioplasty.

It is concluded that coronary artery bypass grafting can be performed safely soon after myocardial infarction provided that left ventricular function is not seriously compromised. Such treatment is more effective than medical treatment for relief of angina during the first year after infarction.

Referral for coronary artery surgery early after acute myocardial infarction presents a dilemma to the cardiovascular team. It has long been maintained that surgery at this stage carries substantial operative risks; recent reports, however, suggest that such estimates of operative mortality and complications may be unduly pessimistic. ${ }^{1-3}$ DeWood et al and Berg et al have reported that surgery can be safely performed in the acute phase of infarction with excellent results. ${ }^{14}$ When pharmacologically uncontrolled angina indicates the likelihood of further deterioration, the indication for surgery is clear, especially since it may be possible to salvage the jeopardised myocardium. The possibility that surgery will improve long term survival or prevent reinfarction in this group of patients, however, has not been proven.

For the past few years we have referred patients

Requests for reprints to Dr R W Brower, Erasmus University, PO Box 1738, 3000 DR Rotterdam, the Netherlands.

Accepted for publication 22 July 1985 for coronary bypass surgery when recurrent angina was refractory to pharmacological treatment, in some patients soon after acute myocardial infarction and in others when angina was induced by mild exertion and associated with severe coronary lesions. It has been our impression that this could be done at low risk and with good long term results.

We have compared results in a group of patients operated on soon after infarction with results in all other patients seen over the same period who received only pharmacological treatment. We have also compared them with a matched pair series of patients at similar risk and with similar symptoms who were not operated on. Over a one year follow up we compared mortality, reinfarction, late referral to bypass surgery or coronary angioplasty, and recurrence of complaints.

The sole criterion for inclusion in the surgery group was that the patient had isolated coronary artery bypass grafting soon after an acute infarction and before hospital discharge. Most had angina pectoris at rest that was resistant to intensive medical treatment. There are always exceptional cases, how- 
ever, generally those with angina during mild exertion or advanced proximal lesions or both. In this study we have chosen to include all cases referred to surgery before hospital discharge after an acute myocardial infarction.

\section{Patients and methods}

Myocardial infarction was diagnosed when at least two of the following were present: typical prolonged chest pain lasting at least 45 minutes; evolving $Q R$ complexes or $Q$ waves of more than $0.04 \mathrm{~s}$ duration with ST and T wave changes in the case of transmural infarction, or $\mathrm{T}$ wave inversion or ST depression persisting for at least 24 hours without loss of the $R$ wave or development of new $Q$ waves in the case of non-transmural infarction; a typical rise and fall of total creatine kinase with a peak activity greater than $100 \mathrm{IU} / 1$ (twice the upper limit for normal in our clinic).

From March 1981 to February 1983 there were 529 admissions with acute infarction. Hospital treatment followed the guidelines described by Simoons et al. ${ }^{5}$ Four cases were referred for surgery because of mitral valve incompetence, ventricular septal defect, or free wall ventricular rupture, and fifteen were treated by elective percutaneous transluminal angioplasty before discharge. These nineteen patients were excluded.

Of the remaining patients, 34 had coronary surgery during the admission for myocardial infarction and 476 did not. In 27 patients the indication for operation was persistent angina pectoris at rest, refractory to medical treatment including beta blockers, calcium antagonists, and nitrates. Three of these patients were in Killip class III or IV during the acute phase of infarction. No patient was in severe heart failure or cardiogenic shock at the time of operation. The seven other patients did not have persisting angina at rest; three of them had angina during mild exertion and they were found to have severe proximal lesions, and four had severe proximal lesions in the infarct related artery after attempted intracoronary thrombolysis with streptokinase. Table 1 summarises the clinical data at entry to the trial. The coronary score ${ }^{6}$ was $15 \cdot 5(8 \cdot 8)$ (mean (SD)), three patients were classified as having proximal three vessel disease, none had exclusively distal vessel disease.

Seventy three $(15 \%)$ of the 476 patients who were not referred to surgery also had post-infarction angina, but they were not offered surgery for various reasons: angina became responsive to medication; there were contraindications to surgery because of severe non-cardiac disease; some refused surgery; and in a few the coronary anatomy was not suitable. Poor left ventricular function was not regarded as a contraindication to coronary bypass operation.

A subgroup of 34 non-operated patients was matched to the operated patients on the basis of age, presence of angina during the hospital stay, Killip class, left ventricular ejection fraction (radionuclide ventriculography) at discharge or before surgery, location of the infarction, peak serum creatine kinase activity, and anatomical severity of coronary artery disease (greater than $\mathbf{5 0} \%$ diameter stenosis, coded

Table 1 Key prognostic variables used to select matched pairs from the larger series of non-operated patients to match the group of operated patients

\begin{tabular}{|c|c|c|c|c|c|}
\hline Variable & Operated & Matched non-operated & $p$ & All non-operated & $p$ \\
\hline $\begin{array}{l}\text { No. of cases } \\
\text { Age (years) } \\
\text { Post-infarction angina at rest } \\
\text { Ejection fraction }\end{array}$ & $\begin{array}{l}34 \\
60 \cdot 7(6 \cdot 1) \\
27(79 \%) \\
0 \cdot 48(0 \cdot 14) \\
(31 \text { cases) }\end{array}$ & $\begin{array}{l}34 \\
55.5(8.9) \\
25(74 \%) \\
0.49(0.11) \\
\text { (34 cases) }\end{array}$ & $\begin{array}{l}\overline{0.01} \\
\text { NS } \\
\text { NS }\end{array}$ & $\begin{array}{l}476 \\
58 \cdot 3(11 \cdot 6) \\
73(15 \%) \\
0 \cdot 45(0 \cdot 16) \\
\text { (358 cases) }\end{array}$ & $\begin{array}{l}\text { NS } \\
0.0001 \\
\star\end{array}$ \\
\hline $\begin{array}{l}\text { Location of MI: } \\
\text { Transmural anterior } \\
\text { Transmural inferior } \\
\text { Non-transmural } \\
\text { Undefinable/unknown }\end{array}$ & $\begin{array}{l}9(26 \%) \\
10(29 \%) \\
15(44 \%) \\
0\end{array}$ & $\begin{array}{l}10(29 \%) \\
9(26 \%) \\
15(44 \%) \\
0\end{array}$ & NS & $\begin{array}{l}189(40 \%) \\
177(37 \%) \\
102(21 \%) \\
8\end{array}$ & 0.025 \\
\hline $\begin{array}{l}\text { Peak serum CK (IU/1) } \\
\text { Killip class: }\end{array}$ & $420(390)$ & $420(320)$ & $\begin{array}{l}\text { NS } \\
\text { NS }\end{array}$ & $610(530)$ & $\begin{array}{l}0.05 \\
0.025\end{array}$ \\
\hline II & $\begin{array}{l}25(74 \%) \\
6(18 \%) \\
3(9 \%)\end{array}$ & $\begin{array}{l}25(74 \%) \\
6(18 \%) \\
3(9 \%)\end{array}$ & & $\begin{array}{l}278(58 \%) \\
113(24 \%) \\
85(18 \%)\end{array}$ & \\
\hline $\begin{array}{l}\text { Anatomical severity: } \\
1 \text { or } 2 \text { vessel disease } \\
3 \text { vessel or left main vessel disease } \\
\text { Unavailable }\end{array}$ & $\begin{array}{l}15(44 \%) \\
19(56 \%) \\
0\end{array}$ & $\begin{array}{l}18(53 \%) \\
16(47 \%) \\
0\end{array}$ & NS & $\begin{array}{l}111(23 \%) \\
43(9 \%) \\
322(68 \%)\end{array}$ & $\star$ \\
\hline
\end{tabular}

Data are reported as events and percentage of cases or as mean (SD). Statistical comparisons: non-operated vs operated; NS, difference not significant at the 0.05 level.

\#No statistical comparison because large numbers of entries were missing.

MI, myocardial infarction; CK, creatine kinase. 
as $(a)$ one or two vessel disease or $(b)$ three vessel disease or worse) (Table 1). Mean (SD) coronary score $^{6}$ was $12 \cdot 5(6 \cdot 5)$, one case was classified as having proximal three vessel disease and five cases having exclusively distal vessel disease.

Medication in the operated patients (at referral to surgery) was compared with that in the nonoperated matched pairs: beta blockers in $85 \%$ of operated vs $80 \%$ non-operated, calcium antagonists in $85 \%$ vs $60 \%$, nitrates in $85 \%$ vs $70 \%$, digoxin in $18 \%$ vs $15 \%$, and diuretics in $29 \%$ vs $33 \%$. Treatment at discharge for all 476 non-operated patients included beta blockers in $44 \%$, calcium antagonists in $19 \%$, nitrates in $33 \%$, digoxin in $25 \%$, and diuretics in $38 \%$. The median duration from onset of the infarction to operation was 20 days (range 6 to 43 days); $97 \%$ were operated on within 35 days. For those patients referred for operation, treatment with analgesics and sedatives had already been started, hence additional premedication was usually not required. Intravenous fentanyl $15 \mu \mathrm{g} / \mathrm{kg}$ was used for induction of anaesthesia and $0.1 \mathrm{mg} / \mathrm{kg}$ pancuronium was given to facilitate intubation. Treatment with intravenous glyceryl trinitrate and inotropics was determined on the basis of arterial pressure monitoring and in principle drug treatment continued until extracorporal circulation was established. The patient was ventilated with a servoventilator with a mixture of oxygen and nitrous oxide (40:60). Additional intravenous fentanyl and possibly pancuronium were given as required before sternotomy and later during operation.

Coronary artery bypass grafting was performed with moderate systemic hypothermia $\left(28^{\circ} \mathrm{C}\right)$ and cardioplegic arrest in combination with topical cooling by means of a saline solution $\left(4^{\circ} \mathrm{C}\right)$. Cardioplegic arrest was accomplished by use of at least $500 \mathrm{ml}$ of St Thomas's solution (sodium chloride $91.6 \mathrm{mmol} / \mathrm{l}$, potassium chloride $14.8 \mathrm{mmol} / \mathrm{l}$, magnesium sulphate $1.2 \mathrm{mmol} / 1$, magnesium chloride $15 \mathrm{mmol} / \mathrm{l}$, potassium dihydrogen phosphate $1.2 \mathrm{mmol} / 1$, calcium chloride $1.2 \mathrm{mmol} / \mathrm{l}$, and hydrochloride pro- caine $1.0 \mathrm{mmol} / \mathrm{l})$. This was administered through the aortic root after cross clamping. If cross clamping lasted more than one hour after the initial infusion, cardioplegia was repeated every 60 minutes to maintain a flat electrocardiogram.

A jump graft was constructed with a saphenous vein graft to all coronary arteries which had stenosis of $50 \%$ or more. One sequential vein graft was routinely used and all distal anastomoses were made during cardioplegic arrest. The proximal anastomosis was made after removing the cross clamp during rewarming. The average revascularisation rate was 3.5 grafts per patient ( 6 cases with 5 grafts, 11 with 4,10 with 3 , and 7 with 2 ). Sinus rhythm usually returned spontaneously. The left ventricle was always vented by means of a left ventricular drain.

Ventilation in the postoperative period was continued until the patient awoke and was haemodynamically stable. Hypertension was treated with nitroprusside. The patient was extubated on the same day as operation or the next morning.

\section{Results}

Compared with the 476 non-operated cases, the 34 operated cases had a greater frequency of nontransmural infarction, were more often in Killip class I, and had lower mean peak serum creatine kinase values, indicating less myocardial damage from the acute infarction. The ejection fraction, however, appeared to be similar in both groups, but it was not known in 61 of $70(87 \%)$ of patients who died in hospital compared with 60 of $444(14 \%)$ hospital survivors. The mean(SD) ejection fraction of $0.45(0.16)$ for non-operated cases, because it is derived from the group containing the larger fraction of deaths, may therefore overestimate the true ejection fraction for this group. Finally, the in-hospital mortality rate was 3\% for operated cases $v s 14 \%$ for all 476 non-operated cases (Table 2). All these

Table 2 Clinical information before discharge from hospital

\begin{tabular}{|c|c|c|c|c|c|}
\hline Variable & Operated & Matched non-operated & $p$ & All non-operated & $p$ \\
\hline $\begin{array}{l}\text { No. of cases } \\
\text { Males } \\
\text { History of angina of more than } 4 \text { weeks } \\
\text { History of old MI } \\
\text { Wedge pressure (mm } \mathrm{Hg} \text { ) at admission } \\
\text { Cardiac index in CCU at admission } \\
\text { Systemic arterial pressure } \\
\text { Length of hospital stay } \\
\text { Recurrent MI in hospital } \\
\text { Death in hospital }\end{array}$ & $\begin{array}{l}34 \\
27(79 \%) \\
22(65 \%) \\
17(50 \%) \\
9 \cdot 8(6 \cdot 1) \\
3 \cdot 1(1 \cdot 1) \\
119(20) \\
22(10) \\
4(12 \%) \\
1(3 \%)\end{array}$ & $\begin{array}{l}34 \\
29(85 \%) \\
11(32 \%) \\
17(50 \%) \\
11 \cdot 1(4 \cdot 5) \\
2 \cdot 8(0 \cdot 7) \\
126(23) \\
18(15) \\
3(9 \%) \\
1(3 \%)\end{array}$ & $\begin{array}{l}\text { NS } \\
0 \cdot 01 \\
\text { NS } \\
\text { NS } \\
\text { NS } \\
\text { NS } \\
\text { NS } \\
\text { NS } \\
\text { NS }\end{array}$ & $\begin{array}{l}476 \\
377(79 \%) \\
164(34 \%) \\
145(30 \%) \\
13 \cdot 3(6 \cdot 6) \\
2 \cdot 6(0 \cdot 8) \\
121(25) \\
12(10) \\
24(5 \%) \\
69(14 \%)\end{array}$ & $\begin{array}{l}\overline{N S} \\
0.0005 \\
0.02 \\
0.05 \\
0.05 \\
\text { NS } \\
0.0001 \\
\text { NS } \\
0.07\end{array}$ \\
\hline
\end{tabular}

Data are reported as events and percentages of cases or as mean (SD). Statistical comparisons: non-operated vs operated; NS, difference not significant at the 0.05 level.

MI, myocardial infarction; CCU, coronary care unit. 
results indicate that patients referred for coronary artery bypass grafts were generally in a better condition overall after their myocardial infarction than were the non-operated patients. Therefore some form of matching is required to obtain a meaningful comparison between the operated and non-operated patients.

The size of the infarction appeared to have a bearing on the timing of operation; when peak serum creatine activity was $<400 \mathrm{IU} / 1$ the median delay from date of myocardial infarction to operation was 14 days compared with 26 days when creatine kinase was $\geqslant 400 \mathrm{IU} / 1$.

One year survival in the operated cases was $94 \%$ compared with $91 \%$ in matched non-operated cases (Table 3). Two patients in the operated group died; both had had post-infarction angina and were in congestive heart failure in the acute phase of infarction. The first death, in a man aged 65 , occurred in the perioperative period and 7 days after the infarction. He had an inferior infarction with peak serum creatine kinase activity of $530 \mathrm{IU} / 1$, an ejection fraction of 0.37 , and three vessel disease. Death was caused by low cardiac output syndrome. All grafts were found to be thrombosed. The second death, in a man aged 64 , occurred 5 months after infarction and was caused by congestive heart failure. He had had an extensive inferior infarction with peak serum creatine kinase activity of 1595 IU/l.

There were three deaths in the matched nonoperated group. The first occurred 26 days after infarction due to cardiac rupture in a 60 year old man (inferior infarction, peak serum creatine kinase activity $400 \mathrm{IU} / 1$, ejection fraction 0.41 , three vessel disease, and with congestive heart failure in the acute phase). This patient did not have postinfarction angina in the acute phase but the other two did. The second death occurred at 70 days due to progressive cardiac failure in a 50 year old man (anterior infarction, peak serum creatine kinase activity $1360 \mathrm{IU} / 1$, ejection franction $0 \cdot 18$, three vessel disease). The third death occurred at 67 days due to congestive heart failure in a 67 year old man (anterior infarction, peak serum creatine kinase activity $130 \mathrm{IU} / 1$, ejection fraction $0 \cdot 24$, history of previous infarctions, three vessel disease).

Among the survivors at one year (32 operated, 31 matched non-operated, and 356 non-operated cases) there were several highly significant differences. Cardiological events were infrequent in the operated cases; only one patient had angina and another had symptoms of congestive heart failure. Of the 356 survivors in the non-operated group, 143 reported angina by one year ( $43 \%$ of survivors), 57 had had an episode of congestive heart failure $(16 \%$ of survivors), and 30 were eventually referred to coronary artery bypass graft surgery ( $8 \%$ of survivors). The comparison of operated survivors with the matched non-operated patients is even more striking. Of the 31 matched non-operated survivors, $23(74 \%)$ had angina by one year (five with angina Killip class IV, six with class III, and twelve with class II) and 10 were referred for late coronary artery bypass surgery $(32 \%)$. The frequency of recurrent infarction and congestive heart failure, however, is similar to that in the operated cases.

Since the indication for coronary artery bypass grafting shortly after an acute infarction is recurrent angina resistant to medical treatment, it is pertinent to ask whether these cases differ in any other important way from those without post-infarction angina. To avoid a selection bias, we considered only those patients who survived the first $\mathbf{7 2}$ hours after the acute event. Ninety eight patients presented with such post-infarction angina $(21 \%$ of 472 patients surviving three days or more) (Table 4). There were no significant differences in the distribution of age, sex, or history of a previous infarction, although cases with recurrent angina do have a longer history of angina before the acute event. Ventricular function is virtually identical in the two groups as is one year survival. At discharge beta blockers, nitrates, and calcium antagonists were more frequently being given to patients with post-infarction angina.

Table 3 Follow up of patients after discharge from hospital

\begin{tabular}{|c|c|c|c|c|c|}
\hline Variable & Operated & Matched non-operated & $p$ & All non-operated & $p$ \\
\hline $\begin{array}{l}\text { No. of cases } \\
\text { Death after discharge } \\
\text { Survival at } 1 \text { year } \\
\text { Recurrent MI by } 1 \text { year } \\
\text { Angina by } 1 \text { year } \\
\text { CHF within } 1 \text { year } \\
\text { CABG within } 1 \text { year } \\
\text { PTCA within } 1 \text { year }\end{array}$ & $\begin{array}{l}34 \\
1(3 \%) \\
32(94 \%) \\
0(0 \%) \\
1(3 \%) \\
1(3 \%) \\
0(0 \%) \\
0(0 \%)\end{array}$ & $\begin{array}{l}34 \\
2(6 \%) \\
31(91 \%) \\
0(0 \%) \\
23(68 \%) \\
2(6 \%) \\
10(29 \%) \\
1(3 \%)\end{array}$ & $\begin{array}{l}-\overline{N S} \\
\text { NS } \\
\text { NS } \\
0.0001 \\
\text { NS } \\
0.001 \\
\text { NS }\end{array}$ & $\begin{array}{c}476 \\
51(11 \%) \\
356(75 \%) \\
27(6 \%) \\
153(32 \%) \\
57(12 \%) \\
30(6 \%) \\
5(1 \%)\end{array}$ & $\begin{array}{l}- \\
\text { NS } \\
0.02 \\
\text { NS } \\
0.0001 \\
0.05 \\
\text { NS } \\
\text { NS }\end{array}$ \\
\hline
\end{tabular}

Data reported as events and percentage of cases. Statistical comparisons: non-operated vs operated; NS, difference not significant at the 0.05 level.

MI, myocardial infarction; CHF, congestive heart failure; CABG, coronary artery bypass graft surgery; PTCA, percutaneous transluminal coronary angioplasty. 


\section{Discussion}

Earlier reports on the outcome of bypass operations peformed soon after acute myocardial infarction were not encouraging. In 1974 Dawson et al reported a hospital mortality rate of $14.5 \%$ in 145 patients operated on within two months of an acute myocardial infarction and a rate of $38 \%$ in those operated within one week. ${ }^{7}$ At that time hospital mortality for elective coronary artery bypass graft surgery in patients without a recent myocardial infarction was $6.2 \%$ at the same hospital. Because this latter figure is considerably higher than that currently reported ${ }^{89}$ (less than $2 \%$ at most hospitals), it is likely that the surgical mortality for patients with acute infarction has also fallen, and, indeed, recent reports clearly demonstrate this fact. In 1983 Williams et al reported a hospital mortality rate of $2 \%$ in patients operated on within 30 days of infarction, ${ }^{2}$ and Nunley et al reported a 3\% operative mortality rate in those operated on within two weeks of infarction; this was in a subgroup of 66 patients with threatened extension of infarction. ${ }^{3}$ In our series the operative mortality is one case out of $34(3 \%)$ while the one year survival (94\%) accords with the recent reports mentioned above. The current operative mortality rate at our institution for all aortocoronary bypass surgery is $1.2 \%$ with a 5 year survival of $93.5 \%{ }^{10}$ While surgical mortality after acute infarction has apparently improved greatly over the past decade, it still falls somewhat short of the excellent results of elective surgery.

It should be borne in mind that our results are based on a retrospective study with all the limitations inherent in such an approach, and despite matching major differences remain between the two groups-these are responsiveness to medical treatment, unsuitable coronary anatomy for bypass surgery, and important non-cardiac disease. For example, five patients in the non-operated group had exclusively distal vessel disease whereas none of the operated group did.

There has been a substantial improvement in surgical technique and postoperative care since the early 1970 s, and we agree with Nunley et $\mathrm{al}^{3}$ that current results do mitigate the concern about attempting an early operation in patients with postinfarction angina. Nevertheless, we should continue to exercise caution. Because the current policy generally excludes patients with extensive ventricular dysfunction, much of the risk of surgery has been eliminated at the outset. This is borne out by the fact that the two deaths in the operated group, one at 7 days and the other at 5 months, occurred in patients with poor left ventricular function. Furthermore, it has been our policy to select patients in whom the infarction is small or caused relatively little functional impairment or both. Such patients would be expected to have a better prognosis whether or not they were operated on early, and this assumption is supported by the results in the matched pair series.

We found no significant difference in survival between patients with or without post-infarction angina (Table 4), nor was there a significant difference in survival between those operated on and the matched non-operated patients. It is doubtful whether operation would materially affect one year survival in any event since it was carried out too late to influence the primary infarct size itself. ${ }^{11}$ DeWood et al ${ }^{1}$ and Berg et $a l^{4}$ have reported that operation at a sufficiently early stage of infarction may limit infarct size and improve survival, although this can not be taken as proven since their patients formed a consecutive series without concurrent controls. The major benefit of surgery in our

Table 4 Comparison of patients without and with post-infarction angina who survived the first 72 hours after myocardial infarction (472 patients)

\begin{tabular}{|c|c|c|c|}
\hline Variable & $\begin{array}{l}\text { No post }-M I \\
\text { angina }\end{array}$ & $\begin{array}{l}\text { Post-MI } \\
\text { angina }\end{array}$ & $p$ \\
\hline $\begin{array}{l}\text { No of cases } \\
\text { Age (years) } \\
\text { Males } \\
\text { Length of stay (days) } \\
\text { Ejection fraction }\end{array}$ & $\begin{array}{l}374 \\
57(12) \\
301(80 \%) \\
12 \cdot 9(8 \cdot 8) \\
0 \cdot 45(0 \cdot 16) \\
(303 \text { cases) } \\
114(30 \%)\end{array}$ & $\begin{array}{l}98 \\
60(10) \\
75(77 \%) \\
18 \cdot 8(10 \cdot 7) \\
0 \cdot 46(0 \cdot 13) \\
(86 \text { cases) } \\
36(37 \%)\end{array}$ & $\begin{array}{l}- \\
\text { NS } \\
\text { NS } \\
0 \cdot 001 \\
\text { NS }\end{array}$ \\
\hline $\begin{array}{l}\text { History of old MI } \\
\text { History of AP for more }\end{array}$ & $114(30 \%)$ & $36(37 \%)$ & NS \\
\hline $\begin{array}{l}\text { than } 4 \text { weeks } \\
\text { Location of } \mathrm{MI} \text { : }\end{array}$ & $110(29 \%)$ & $61(62 \%)$ & $\begin{array}{l}0.001 \\
\text { NS }\end{array}$ \\
\hline $\begin{array}{l}\text { Transmural anterior } \\
\text { Transmural inferior } \\
\text { Non-transmural } \\
\text { Unknown/undefinable } \\
\text { Peak serum CK (IU/1) } \\
\text { Killip clinical class: }\end{array}$ & $\begin{array}{l}144(38 \%) \\
139(37 \%) \\
85(23 \%) \\
6 \\
620(540)\end{array}$ & $\begin{array}{l}31(32 \%) \\
34(35 \%) \\
32(33 \%) \\
1 \\
520(420)\end{array}$ & $\begin{array}{l}\text { NS } \\
\text { NS }\end{array}$ \\
\hline $\begin{array}{l}\text { I } \\
\text { II } \\
\text { III } \\
\text { IV } \\
\text { Wedge presure }(\mathrm{mm} \mathrm{Hg}) \\
\text { Cardiac index }\left(1 / \mathrm{min} / \mathrm{m}^{2}\right) \\
\text { Mean arterial pressure }\end{array}$ & $\begin{array}{l}237(63 \%) \\
90(24 \%) \\
23(6 \%) \\
24(6 \%) \\
12 \cdot 9(6 \cdot 5) \\
2 \cdot 8(0 \cdot 8)\end{array}$ & $\begin{array}{l}64(65 \%) \\
24(24 \%) \\
6(6 \%) \\
4(4 \%) \\
11 \cdot 3(6 \cdot 0) \\
2 \cdot 6(0 \cdot 8)\end{array}$ & $\begin{array}{l}\text { NS } \\
\text { NS }\end{array}$ \\
\hline $\begin{array}{l}\text { ( } \mathrm{mm} \mathbf{~ H g}) \\
\text { Death in hospital } \\
\text { Death after discharge }\end{array}$ & $\begin{array}{l}123(22) \\
27(7 \%)\end{array}$ & $\begin{array}{l}123(20) \\
5(5 \%)\end{array}$ & $\begin{array}{l}\text { NS } \\
\text { NS }\end{array}$ \\
\hline $\begin{array}{l}\text { within one year } \\
\text { Non-fatal reinfarction } \\
\text { Total one year survival } \\
\text { Medication at discharge: }\end{array}$ & $\begin{array}{l}39(10 \%) \\
43(11 \%) \\
317(85 \%)\end{array}$ & $\begin{array}{l}13(13 \%) \\
12(12 \%) \\
83(85 \%)\end{array}$ & $\begin{array}{l}\text { NS } \\
\text { NS } \\
\text { NS }\end{array}$ \\
\hline $\begin{array}{l}\text { Anticoagulants } \\
\text { Beta blockers } \\
\text { Digoxin } \\
\text { Diuretics } \\
\text { Nitrates } \\
\text { Calcium antagonists } \\
\text { Antiarrhythmics }\end{array}$ & $\begin{array}{l}74(20 \%) \\
147(39 \%) \\
88(24 \%) \\
129(34 \%) \\
91(24 \%) \\
46(12 \%) \\
18(5 \%)\end{array}$ & $\begin{array}{l}19(19 \%) \\
63(64 \%) \\
18(18 \%) \\
37(38 \%) \\
73(74 \%) \\
60(61 \%) \\
4(4 \%)\end{array}$ & $\begin{array}{l}\text { NS } \\
0.001 \\
\text { NS } \\
\text { NS } \\
0.001 \\
0.001 \\
\text { NS }\end{array}$ \\
\hline
\end{tabular}

Data reported as events and percentage of cases or as mean (SD). All percentages computed over entire series of 374 and 98 cases respectively. NS, difference not significant at the 0.05 level. MI, myocardial infarction; AP, angina pectoris; $C K$, creatine kinase. 
series thus is the effective management of refractory post-infarction angina. Nevertheless, the decision to perform bypass grafting for this indication soon after infarction remains a matter requiring careful judgment in each patient.

These data were gathered during a period when percutaneous transluminal coronary angioplasty started to gain acceptance at our institution. It is clear that angioplasty is having an impact on our policy to refer patients for operation; more patients receive angioplasty first, and those with unsatisfactory results or complications are later referred for operation. ${ }^{12}$ Meyer et al have reported that angioplasty can be carried out at low risk and with good early and late results in patients with unstable angina pectoris. ${ }^{13}$ But results from randomised trials designed to evaluate the long term success rate of this policy have not yet appeared. Also it remains to be seen what effect the widespread availability of thrombolytic agents such as recombinant tissue type plasminogen activator ${ }^{14}$ will have on the management of these patients.

In summary, the results presented here for coronary artery bypass surgery after acute myocardial infarction show that this procedure can be carried out with low operative mortality and one year mortality. In patients with post-infarction angina in whom an extension of infarction is threatened operation should be considered provided that the infarct is small and that left ventricular function is good. We must emphasise, however, that if angina can be controlled by medical treatment early after infarction, then this remains the preferred approach. The most striking difference between the operated and non-operated matched pairs is the recurrence of angina within one year that required aggressive medical treatment, angioplasty, or coronary bypass graft surgery.

\section{References}

1 DeWood MA, Heit J, Spores J, et al. Anterior transmural myocardial infarction: effects of surgical coronary reperfusion on global and regional left ventricular function. $f$ Am Coll Cardiol 1983; 1: 1223-34.

2 Williams DB, Ivey TD, Bailey WW, Irey SJ, Rideout
JT, Stewart D. Postinfarction angina: results of early revascularization. $\mathcal{A}$ Am Coll Cardiol 1983; 2: 859-64.

3 Nunley DL, Grunkemeier GL, Teply JF, et al. Coronary bypass operation following acute complicated myocardial infarction. $\mathcal{F}$ Thorac Cardiovasc Surg 1983; 85: 485-91.

4 Berg R Jr, Selinger SL, Leonard JJ, Coleman WS, DeWood $M$. Acute evolving myocardial infarction. $\mathcal{f}$ Thorac Cardiovasc Surg 1984; 88: 902-6.

5 Simoons ML, Serruys PW, Fioretti P, van den Brand M, Hugenholtz PG. Practical guidelines for treatment with beta-blockers and nitrates in patients with acute myocardial infarction. Eur Heart $\mathcal{F}$ 1983; 4 (suppl D): 129-35.

6 Leaman DM, Brower RW, Meester GT, Serruys PW, van den Brand $M$. Coronary artery atherosclerosis: severity of the disease, severity of angina pectoris and compromised left ventricular function. Circulation 1981; 63: 285-92.

7 Dawson JT, Hall RJ, Hallman GL, Cooley DA. Mortality in patients undergoing coronary artery bypass surgery after myocardial infarction. Am $\mathcal{F}$ Cardiol 1974; 33: 483-6.

8 Rahimtoola SH, Nunley D, Grunkemeier G, Tepley J, Lambert L, Starr A. Ten-year survival after coronary bypass surgery for unstable angina. $N$ Engl $\mathcal{F}$ Med 1983; 308: 676-81.

9 Gersh BJ, Kronmal RA, Frye RL, et al. Coronary arteriography and coronary artery bypass surgery: morbidity and mortality in patients aged 65 years or older. A report from the Coronary Artery Surgery Study. Circulation 1983; 67: 483-91.

10 Laird-Meeter K, ten Katen HJ, van Domburg R, et al. Tien jaar coronairia chirurgie: resultaten bij 1041 patienten, geopereerd in het Thoraxcentrum te Rotterdam. Ned Tijdschr Geneeskd 1983; 127: 988-94.

11 Fioretti P, Brower RW, Simoons ML, et al. Prediction of mortality in hospital survivors of myocardial infarction. Br Heart $\mathcal{F}$ 1984; 52: 292-8.

12 de Feyter P, Serruys P, Brand M vd, et al. Emergency coronary angioplasty in refractory unstable angina: immediate and follow-up results. $N$ Engl $₹$ Med 1985; 313: $342-6$.

13 Meyer J, Schmitz H, Kiesslich T, et al. Percutaneous transluminal coronary angioplasty in patients with stable and unstable angina pectoris: analysis of early and late results. Am Heart f 1983; 106: 973-80.

14 Verstraete M, Bernard R, Bory M, et al. Randomised trial of intravenous recombinant tissue-type plasminogen activator versus intravenous streptokinase in acute myocardial infarction. Lancet 1985; i: 842-7. 